\title{
UJI DAYA HAMBAT EKSTRAK RIMPANG LENGKUAS MERAH (Alpinia purpurata K.Schum) TERHADAP PERTUMBUHAN BAKTERI Klebsiella pneumoniae ISOLAT SPUTUM PADA PENDERITA PNEUMONIA RESISTEN ANTIBIOTIK SEFTRIAKSON
}

\author{
Poetry Melinda S Abubakar ${ }^{1)}$, Fatimawali' ${ }^{1)}$, Paulina V. Y. YamLean ${ }^{1)}$ \\ ${ }^{1)}$ Program Studi Farmasi FMIPA UNSRAT Manado, 95115
}

\begin{abstract}
Red galangal rhizome is a plant that has various properties including antifungal and antibacterial. Red galangal rhizomes contain a class of flavonoids, phenols and terpenoids, which can be, used as basic ingredients of modern medicines. Flavonoids and phenols are also known to inhibit microbes. Flavonoids can inhibit microbes that have been resistant to antibiotics. This study aims to determine the antibacterial activity of red galangal rhizome extract (Alpinia purpurata K.Schum) and test its inhibitory effect on the growth of Klebsiella pneumoniae bacteria in sputum isolates in patients with pneumonia resistant ceftriaxone antibiotics. Red galangal rhizome plant was extracted by maceration method using $96 \%$ ethanol. Antibacterial inhibitory tests were carried out using the disc and well method. The results showed that the red galangal extract of rhizome had a inhibitory effect on the bacterium Klebsiella pneumoniae. On the disc method for concentrations of 100\%, 75\%, 50\%, 25\% and 12.5\% the diameter of the inhibition zone is $9.6 \mathrm{~mm}, 8.68 \mathrm{~mm}, 8.5 \mathrm{~mm}, 8.5 \mathrm{~mm}$ and $7.6 \mathrm{~mm}$. The inhibition ability of bacterial growth on the disc method is categorized as moderate because it has an average inhibition zone diameter of 5-10 mm. Whereas in the well method for concentrations of $100 \%, 75 \%, 50 \%$, 25\% and $12.5 \%$ the diameter of the inhibition zone was $25.8 \mathrm{~mm}, 20 \mathrm{~mm}, 15.6 \mathrm{~mm}, 12.7 \mathrm{~mm}$ and $9.7 \mathrm{~mm}$, respectively. The inhibition ability of bacterial growth in the well method for $100 \%$ concentration is categorized as very strong because it has an average inhibition zone diameter of $>20 \mathrm{~mm}$, for concentrations of $75 \%, 50 \%$ and 25\% it is categorized as strong because it has an average inhibition zone of 10- $20 \mathrm{~mm}$ and for a concentration of $12.5 \%$ it is categorized as moderate because it has an average inhibition zone diameter of $5-10 \mathrm{~mm}$.
\end{abstract}

Keywords: Red galangal rhizome, Alpinia purpurata K.Schum, Klebsiella pneumonia

\begin{abstract}
ABSTRAK
Rimpang Lengkuas merah merupakan tanaman yang memiliki berbagai khasiat di antaranya sebagai antijamur dan antibakteri. Rimpang Lengkuas merah mengandung golongan senyawa flavonoid, fenol dan terpenoid yang dapat digunakan sebagai bahan dasar obat-obatan moderen. Senyawa flavonoid dan fenol juga diketahui dapat menghambat mikroba. Flavonoid dapat menghambat mikroba yang telah resisten terhadap antibiotik. Penelitian ini bertujuan untuk mengetahui aktivitas antibakteri ekstrak rimpang Lengkuas merah (Alpinia purpurata K.Schum) dan menguji daya hambatnya terhadap pertumbuhan bakteri Klebsiella pneumoniae isolat sputum pada penderita pneumonia resisten antibiotik seftriakson. Tanaman rimpang Lengkuas merah di ekstraksi dengan metode maserasi menggunakan pelarut etanol 96\%. Uji daya hambat antibakteri dilakukan dengan metode cakram dan sumuran. Hasil penelitian menunjukkan bahwa ekstrak rimpang Lengkuas merah memiliki daya hambat terhadap bakteri Klebsiella pneumoniae. Pada metode cakram untuk konsentrasi 100\%, 75\%, 50\%, 25\% dan 12,5\%
\end{abstract}


diameter zona hambatnya ialah $9,6 \mathrm{~mm}, 8,68 \mathrm{~mm}, 8,5 \mathrm{~mm}, 8,5 \mathrm{~mm}$ dan 7,6 $\mathrm{mm}$. Kemampuan penghambatan pertumbuhan bakteri pada metode cakram di kategorikan sedang karena memiliki diameter zona hambat rata-rata 5-10 mm. Sedangkan pada metode sumuran untuk konsentrasi $100 \%, 75 \%, 50 \%$, $25 \%$ dan $12,5 \%$ diameter zona hambatnya ialah $25,8 \mathrm{~mm}, 20 \mathrm{~mm}, 15,6 \mathrm{~mm}, 12,7 \mathrm{~mm}$ dan $9,7 \mathrm{~mm}$. Kemampuan penghambatan pertumbuhan bakteri pada metode sumuran untuk konsentrasi $100 \%$ di kategorikan sangat kuat karena memiliki diameter zona hambat rata-rata $>20 \mathrm{~mm}$, untuk konsentrasi $75 \%$, $50 \%$ dan $25 \%$ di kategorikan kuat karena memiliki diameter zona hambat rata-rata 10-20 mm dan untuk konsentrasi $12,5 \%$ di kategorikan sedang karena memiliki diameter zona hambat rata-rata 5-10 mm.

Kata Kunci:Rimpang Lengkuas merah, Alpinia purpurata K.Schum, Klebsiella pneumonia 


\section{PENDAHULUAN}

Penyakit infeksi merupakan jenis penyakit yang paling banyak diderita oleh penduduk di negara berkembang, termasuk Indonesia. Salah satu penyebab penyakit infeksi ialah mikroorganisme bakteri (Radji, 2011). Penyakit yang diakibatkan oleh infeksi mikroorganisme merupakan salah satu penyakit yang selalu menjadi pusat perhatian para praktisi dan pemerhati kesehatan (Wattimena, 1990). Salah satu penyakit infeksi akibat bakteri ialah pneumonia.

Pneumonia adalah peradangan parenkrim paru dimana asinus terisi dengan cairan dan sel radang, dengan atau tanpa disertai infiltrasi sel radang ke dalam dinding alveoli dan rongga interstisium (Mukty dan Alsagaff, 2010). Penyakit ini sering menyerang anak balita, namun dapat juga ditemukan pada orang dewasa. Infeksi pneumonia merupakan infeksi akut yang mengenai jaringan paru-paru (alveoli). Gejala pneumonia pada umumnya antara lain demam, sesak napas, napas dan nadi berdenyut lebih cepat, dahak berwarna kehijauan atau seperti karet (Misnadiarly, 2008). Salah satu bakteri penyebab pneumonia bakteri Streptococcus pneumoniae, bakteri Staphylococcus aureus dan bakteri Klebsiella pneumoniae (Brisse et al.,2009).

Pengobatan klinis untuk menangani penyakit infeksi penggunaan antibiotik sangat diperlukan. Tingginya penggunaan antibiotik secara tidak tepat dikalangan masyarakat saat ini menyebabkan terjadinya masalah resistensi antibiotik. Menurut penelitian Harum 2018 bakteri Klebsiella pneumoniae merupakan penyebab penyakit pneumonia yang resisten terhadap antibiotik Setriakson. Permasalahan resisten terjadi ketika bakteri berubah yang menyebabkan turun atau hilangnya efektivitas obat atau senyawa kimia yang digunakan untuk mencegah atau mengobati infeksi (Utami, 2012).

Tingginya angka kematian yang disebabkan oleh penyakit infeksi mengharuskan kita untuk melakukan pengobatan yang maksimal. Indonesia merupakan negara yang terkenal dengan keanekaragam tanaman terutama hasil pertanian dan rempahrempah. Hal ini didukung oleh keadaan geografis Indonesia yang beriklim tropis dengan curah hujan rata-rata tinggi sepanjang tahun. Sumber daya alam yang dimiliki telah memberikan manfaat dalam kehidupan sehari-hari disamping sebagai bahan makanan, juga dimanfaatkan sebagai obat tradisional (Wijayakusuma, 2000).

Keanekaragaman hayati yang memiliki potensi untuk dikembangkan sebagai obat tradisional ialah Lengkuas merah (Alpinia purpurata K.Schum). Rimpang Lengkuas merah selain mengandung minyak atsiri juga mengandung golongan senyawa flavonoid, fenol dan terpenoid. Karena rimpang Lengkuas memiliki kandungan senyawa flavonoid yang diduga mampu menghambat pertumbuhan bakteri yang telah resisten terhadap antibiotik (Yuharmen, 2002).

Hasil penelitian diatas menunjukkan adanya indikasi ekstrak rimpang Lengkuas merah (Alpinia purpurata K.Schum) mempunyai daya antibakteri, maka hal ini menarik perhatian peneliti untuk melakukan 
uji daya hambat ekstrak rimpang Lengkuas merah (Alpinia purpurata K.Schum) terhadap pertumbuhan bakteri Klebsiella pneumoniae isolat sputum pada penderita pneumonia yang resisten terhadap antibiotik seftriakson.

\section{METODE PENELITIAN}

Penelitian ini dilakukan pada bulan Juni - Oktober 2018 di laboratorium Mikrobiologi Program Studi Farmasi Fakultas Matematika dan Ilmu Pengetahuan Alam Universitas Sam Ratulangi Manado.

Alat yang digunakan dalam penelitian yaitu timbangan analitik $\left(\right.$ aeADAM $^{\circledR}$ ), blender (Philips), gelas ukur (Pyrex), tabung reaksi (Pyrex), Erlenmeyer (Pyrex), beker gelas (Pyrex), corong, batang pengaduk, cawan petri Pyrex), kertas saring, ayakan mesh, jarum ose, pecadang, pingset, mikropipet (ecopippette ${ }^{\mathrm{TM}}$ ), waterbath, laminar air flaw (N-Biotecck), autoklav (ALP), incubator (MMM Group), aluminium foil, Hot plate $\left(\mathrm{NESCO}^{\circledR} \mathrm{Lab}\right)$, mistar berskala $\left(\mathrm{Combo}^{\circledR}\right)$, kertas lebel dan spritus.

Bahan yang digunakan dalam penelitian ini yaitu bakteri Klebsiella pneumoniae yang telah resisten terhadap antibiotik, ekstrak rimpang Lengkuas merah, etanol 96\%, aquades, media nutrient agar (NA), kertas cakram, $\mathrm{NaCl} 0,9 \%, \mathrm{H}_{2} \mathrm{SO}_{4}$ $0,36 \mathrm{~N}$ dan $\mathrm{BaCl}_{2} 2 \mathrm{H}_{2} \mathrm{O} 1,175 \%$.

Jenis penelitian ini merupakan eksperimental laboratorium dengan sampel ekstrak etanol tanaman rimpang Lengkuas merah yang dibuat dengan lima variasi konsentrasi $100 \%, 75 \%, 50 \%, 25 \%$ dan $12,5 \%$ dan dilakukan pengujian pada bakteri

\section{Persiapan Sampel}

Sampel yang digunakan diambil dari kelurahan Rurukan, Kecamatan Tomohon Timur, Tomohon, Sulawesi Utara. Sampel yang diambil ialah bagian rimpang Lengkuas merah yang masih segar.

Pada tahap awal sampel rimpang Lengkuas merah ditimbang dengan berat 1,5 $\mathrm{kg}$. Selanjutnya dicuci dengan air mengalir dengan tujuan menghilangkan pengotor. Sampel kemudian dirajang untuk mempermudah proses pengeringan. Pengeringan sampel dilakukan dengan cara diangin-anginkan selama 1 minggu. Sampel yang sudah kering kemudian di blender hingga menjadi serbuk dan ditimbang. Serbuk yang dihasilkan diayak dengan ayakan mesh, hingga diperoleh serbuk halus.

\section{Pembuatan Ekstrak}

Metode yang digunakan untuk mengekstrak rimpang Lengkuas merah (Alpinia purpurata K.Schum), yaitu dengan menggunakan metode maserasi. Ditimbang sebanyak $150 \mathrm{~g}$, kemudian dimasukkan ke wadah tertutup rapat. Sampel yang telah ditimbang diekstraksi dengan $750 \mathrm{~mL}$ etanol 96\% pada suhu kamar selama 5 hari sambil sesekali diaduk. Setelah 5 hari sampel disaring dengan menggunakan kertas saring menghasilkan filtrat satu. Sisanya dimaserasi kembali dengan $450 \mathrm{~mL}$ pelarut etanol $96 \%$ selama 2 hari sambil sesekali diaduk kemudian di saring dengan kertas saring menghasilkan filtrat dua. Filtrat satu dan filtrat dua dikumpulkan dan diuapkan menggunakan waterbath, sehingga diperoleh ekstrak kental Lengkuas merah dengan konsentrasi $100 \%$. 


\section{Sterilisasi Alat}

Sterilisasi alat dilakukan sebelum semua peralatan di gunakan, yaitu dengan cara membungkus semua peralatan dengan aluminium foil kemudian dimasukkan ke dalam autoklaf untuk sterilisasi dengan suhu $121^{\circ} \mathrm{C}$ selama 15 menit.

\section{Pembuatan Media Dasar dan Media Pembenihan}

Diambil Nutrient Agar (NA) sebanyak 5,6 gram dilarutkan dalam 200 $\mathrm{mL}$ aquadest menggunakan erlenmeyer. Setelah itu, media dihomogenkan dengan stirer diatas penangas air sampai mendidih. Media yang sudah homogen ini disterilkan dalam autoklaf pada suhu $121^{\circ} \mathrm{C}$ selama 15 menit, kemudian didinginkan sampai suhu \pm $45-50^{\circ}$ C. Media dasar dan media pembenihan digunakan dalam pembuatan media pengujian sebagai lapisan dasar dan lapisan kedua.

\section{Regenerasi Bakteri}

Bakteri Klebsiella pneumoniae yang akan diujikan, terlebih dahulu harus diregenerasikan. Hal pertama yang dilakukan yaitu membuat media miring nutrien agar (NA). Media (NA) dituangkan kedalam tabung reaksi, kemudian diletakkan pada posisi miring dan didiamkan hingga agar memadat. Selanjutnya menggoreskan biakan dari stok bakteri ke agar miring nutrient agar (NA). kultur bakteri pada masing-masing agar miring diinkubasi pada suhu $37^{\circ} \mathrm{C}$ selam $18-24$ jam.

Pembuatan Larutan Mc.Farland 0,5
Larutan $\mathrm{H}_{2} \mathrm{SO}_{4} \quad 1 \%$ sebanyak 9,95 $\mathrm{mL}$ dicampurkan dengan larutan $\mathrm{BaCl}_{2}$ . $2 \mathrm{H}_{2} \mathrm{O} \quad 1,175 \%$ sebanyak $0,05 \mathrm{~mL}$ dalam erlenmeyer. Kemudian dikocok sampai terbentuk larutan yang keruh. Kekeruhan ini dipakai sebagai standar kekeruhan suspensi bakteri uji (Borges dan Bresson, 2004).

\section{Suspensi Bakteri}

Suspensi bakteri dilakukan dengan cara bakteri uji yang telah diregenerasi diambil dengan jarum ose lalu disuspensikan ke dalam tabung reaksi berisi $5 \mathrm{~mL}$ larutan $\mathrm{NaCl}$ steril 0,9\%. Suspensi yang terbentuk disetarakan kekeruhannya dengan larutan standar Mc farland No.0,5 yaitu 1,5 x $10^{8}$ $\mathrm{CFU} / \mathrm{mL}$.

\section{Pembuatan Larutan}

a. Larutan Stok

Larutan stok dibuat dari hasil ekstraksi yang diperoleh dengan konsentrasi $100 \%$ kemudian diencerkan dengan aquadest sebanyak empat kali pengenceran dengan masing-masing konsentrasi 75\%, 50\%, 25\% dan $12,5 \%$ dengan menggunakan rumus :

b. Larutan Komtror Postur an Kontrol Negatif

Kontrol positif dibuat dari sediaan obat tablet ciprofloxacin $500 \mathrm{mg}$, dengan cara satu tablet ciprofloxacin digerus. Setelah itu di timbang $65 \mathrm{mg}$ dan dilarutkan dalam $50 \mathrm{~mL}$ aquadest, selanjutnya dibuat dengan cara diambil $1 \mathrm{~mL}$ larutan dan ditambahkan aquadest hingga $10 \mathrm{~mL}$ untuk memperoleh larutan ciprofloxacin $5 \mu \mathrm{g} / 50 \mu \mathrm{L}$. Larutan kontrol negatif digunakan aquadest. 


\section{UJI EFFEKTIFITAS}

a. Metode Cakram

Media Nutrien Agar (NA) sebanyak $15 \mathrm{~mL}$ di tuang ke dalam cawan petri dan dibiarkan memadat, kemudiaan dimasukkan $1 \mathrm{~mL}$ suspensi bakteri Klebsiella pneumoniae yang telah dicampurkan ke dalam media pembenihan NA kemudian disebarkan biakan bakteri dengan menggunakan kapas steril agar suspensi tersebar merata pada media dan didiamkan selama 10 menit agar suspensi terserap pada media. Cawan petri tersebut diletakkan kertas cakram ukuran $6 \mathrm{~mm}$ dengan menggunakan pinset steril yang telah direndam dalam aquadest (Kontrol negatif) dan kertas cakram ukuran $6 \mathrm{~mm}$ yang telah direndam dalam larutan uji. Selanjutnya semua media diinkubasi kedalam inkubator, inkubasi dilakukan pada suhu $37^{\circ} \mathrm{C}$ selama 24 jam. Diukur diameter zona bening yang terbentuk dengan menggunakan penggaris millimeter.

b. Metode Sumuran

Media uji dibuat dengan dengan 2 lapisan media agar, yang pengerjaannya seperti berikut :

1.Lapisan dasar dibuat dengan menuangkan masing-masing $15 \mathrm{~mL} N A$ ke masingmasing 3 cawan petri, kemudian dibiarkan memadat.

2.Setelah memadat, permukaan lapisan dasar ditanam 5 pencadang baja yang diatur jaraknya agar daerah pengamatan tidak bertumpu.

3.Suspensi bakteri dicampurkan ke dalam media pembenihan $N A$.
4.Selanjutkan dituangkan $15 \mathrm{~mL} \mathrm{NA}$ pada tiap cawan petri yang diletakan pencadang sebagai lapisan kedua.

5.Setelah lapisan kedua memadat, pencadang diangkat secara aseptik menggunakan pinset dari masing-masing cawan petri, sehingga terbentuk sumur-sumur yang akan digunakan dalam uji bakteri.

6.Sumuran yang terbentuk diisi dengan larutan kontrol dan larutan uji masingmasing $50 \mu 1$.

7.Selanjutnya semua media di inkubasi dalam inkubator pada suhu $37^{\circ} \mathrm{C}$ selama 24 jam.

\section{Pengukuran dan Penetapan Zona Hambat}

Pengamatan dilakukan setelah 1x24 jam masa inkubasi. Zona bening merupakan petunjuk kepekaan mikroba terhadap bahan antimikroba yang digunakan sebagai bahan uji yang dinyatakan dengan lebar diameter zona hambat (Vandepite, 2005). Diameter zona hambat diukur kemudian dikategorikan kekuatan daya antibakterinya berdasarkan penggolongan Davis dan Stout (1971).

\section{HASIL DAN PEMBAHASAN}

\section{Ekstraksi}

Sampel basah rimpang Lengkuas merah diperoleh sebanyak $1,5 \mathrm{~kg}$, dikeringkan dan diblender menghasilkan serbuk simplisia sebanyak 150 gram dan di ekstrak menggunakan cara maserasi. Proses maserasi dilakukan selama 5 hari dengan menggunakan etanol $96 \%$ sebanyak $750 \mathrm{~mL}$ dan remaserasi selama 2 hari menggunakan etanol $96 \% 450 \mathrm{~mL}$ hingga diperoleh hasil maserat etanol Lengkuas merah (filtrat $1+$ filtrat 2) sebanyak $1100 \mathrm{~mL}$. Hasil maserat 
Lengkuas merah ini kemudian diuapkan dengan menggunakan waterbath dengan tujuan menguapkan etanol dari proses maserasi dan menghasilkan ekstrak kental sebayak 11,08 gram.

\section{UJI EFFEKTIFITAS}

a. Metode Cakram

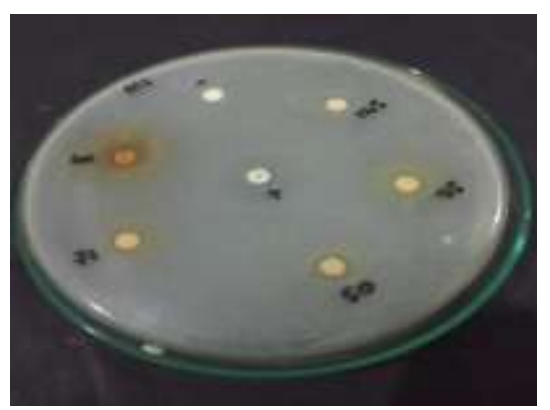

Gambar 1. Hasil Metode Cakram

Tabel 1. Hasil Pengukuran Daya Hambat denganMetode Cakram

\begin{tabular}{ccccc}
\hline Perlakuan & U1 & U2 & U3 & Rata-rata \\
\hline $\mathbf{K}(-)$ & 0 & 0 & 0 & 0 \\
$\mathbf{K}(+)$ & 20 & 23 & 21 & 21,3 \\
$\mathbf{1 0 0 \%}$ & 10 & 9 & 10 & 9,6 \\
$\mathbf{7 5 \%}$ & 7 & 7,5 & 11,5 & 8,68 \\
$\mathbf{5 0 \%}$ & 8 & 10,5 & 7 & 8,5 \\
$\mathbf{2 5 \%}$ & 9 & 8,25 & 8,5 & 8,5 \\
$\mathbf{1 2 , 5 \%}$ & 7,5 & 8,5 & 7 & 7,6 \\
\hline
\end{tabular}

b. Metode Sumuran

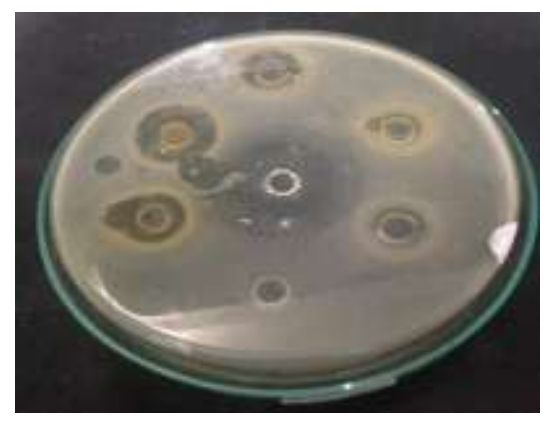

Gambar 2. Hasil Metode Sumuran
Tabel 2. Hasil Pengukuran Daya Hambat dengan Metode Sumuran

\begin{tabular}{|c|c|c|c|c|}
\hline Perlakuan & U1 & $\mathbf{U} 2$ & U3 & Rata-rata \\
\hline$K(-)$ & 0 & 0 & 0 & 0 \\
\hline$K(+)$ & 9 & 14 & 24,8 & 16 \\
\hline $100 \%$ & 18 & 32,5 & 27 & 25,8 \\
\hline $75 \%$ & 14,7 & 26 & 22 & 20 \\
\hline $50 \%$ & 11 & 19 & 17 & 15,6 \\
\hline $25 \%$ & 9,5 & 16,7 & 12 & 12,7 \\
\hline $12,5 \%$ & 9,2 & 10 & 10 & 9,7 \\
\hline
\end{tabular}

pneumoniae menggunakan metode cakram dan metode sumuran. Kedua metode ini menggunakan media Nutrient Agar (NA). Media Nutrient Agar (NA) merupakan medium yang baik sebagai tempat tumbuhnya beberapa bakteri gram positif dan gram negatif yang di manfaatkan sebagai sumber nutrisi bagi pertumbuhan bakteri. Dalam uji effektivitas hasil diperoleh melalui pengamatan yang dilakukan selama 1 x 24 jam masa inkubasi pada suhu $37^{\circ} \mathrm{C}$ dengan 3 kali pengulangan. Pengujian ini menggunakan kontrol positif dan kontrol negatif. Kontrol positif berfungsi sebagai kontrol dari zat uji dengan membandingkan diameter daerah hambat yang terbentuk (Dwijendra, 2014). Kontrol positif yang digunakan antibiotik ciprofloxacin. Menurut Sarro (2001) antibiotik Ciprofloxacin merupakan antibiotik dengan kegiatan luas, yaitu antibiotik yang memiliki aktivitas banyak jenis bakteri, virus, jamur dan protozoa. Kontrol negatif berfungsi untuk mengetahui ada tidaknya pengaruh pelarut terhadap 
pertumbuhan bakteri uji Klebsiella pneumoniae, sehingga dapat diketahui bahwa yang mempunyai aktivitas antibakteri adalah zat uji bukan pelarut (Dwijendra, 2014). Kontrol negatif yang digunakan adalah aquadest.

Dari hasil yang dilakukan untuk metode difusi cakram menunjukan diameter zona hambat dari kontrol positif bakteri uji lebih besar dibandingan dengan ekstrak dan kontrol negatif yaitu $21,3 \mathrm{~mm}$ sedangkan untuk metode sumuran yaitu $16 \mathrm{~mm}$. Untuk kontrol negatif baik untuk metode cakram maupun metode sumuran tidak memperlihatkan adanya daya hambat untuk bakteri uji. Hal ini mengindikasikan bahwa kontrol yang digunakan tidak berpengaruh pada uji antibakteri, sehingga daya hambat yang terbentuk tidak dipengaruhi oleh pelarut melainkan karena aktivitas senyawa yang ada pada rimpang Lengkuas merah. Untuk larutan uji konsentrasi 100\%, 75\%, $50 \%, 25 \%$ dan $12,5 \%$ pada metode cakram rata-rata diameter zona beningnya $9,6 \mathrm{~mm}$, $8,6 \mathrm{~mm}, 8,5 \mathrm{~mm}, 8,5 \mathrm{~mm}$ dan $7,6 \mathrm{~mm}$. Sedangkan pada metode sumuran rata-rata diameter zona beningnya ialah $25,8 \mathrm{~mm}, 20$ $\mathrm{mm}, 15,6 \mathrm{~mm}, 12,7 \mathrm{~mm}$ dan $9,7 \mathrm{~mm}$. Hal ini menunjukkan semakin besar konsentrasi ekstrak rimpang Lengkuas merah yang diberikan, maka semakin besar pula diameter zona bening yang terbentuk.

Tabel 3. Standar Kekuatan Daya Antibakteri Menurut Davis dan Stout (1971)

\begin{tabular}{cc}
\hline $\begin{array}{c}\text { Diameter Zona } \\
\text { Bening }\end{array}$ & Kategori \\
\hline$>20$ & Sangat kuat \\
$10-20$ & Kuat \\
\hline
\end{tabular}

\begin{tabular}{ccc}
\hline $5-10$ & Sedang \\
$<5$ & & Lemah \\
\hline Kriteria inilah & yang & digunakan dalam
\end{tabular}

Kriteria inilah yang digunakan dalam penelitian untuk penggolongan daya hambat larutan uji. Maka daya hambat ekstrak rimpang Lengkuas merah terhadap bakteri Klebsiella pneumonia untuk metode cakram dengan konsentrasi $100 \%, 75 \%, 50 \%, 25 \%$ dan $12,5 \%$ termasuk dalam kategori sedang karena memiliki daya hambat $5-10 \mathrm{~mm}$. Untuk metode sumuran pada konsentrasi $100 \%$ termasuk kategori sangat kuat karena memiliki rata-rata daya hambat $25,8 \mathrm{~mm}$. Untuk konsentrasi $75 \%, 50 \%$ dan 25\% termasuk dalam kategori kuat karena ratarata diameter daya hambatnya $10-20 \mathrm{~mm}$. Dan konsentrasi 12,5\% termasuk kategori sedang karena rata-rata diameter daya hambatnya yaitu $9,7 \mathrm{~mm}$.

Pada penelitian ini metode sumuran menunjukkan hasil yang lebih baik yaitu zona hambat yang terbentuk lebih besar dibandingkan metode cakram. Hal ini terjadi karena banyak faktor dan teori, pada metode sumuran ekstrak langsung di masukkan ke setiap lubang, sehingga efek untuk menghambat bakteri menjadi lebih kuat. Sedangkan pada metode cakram, kertas cakram harus di rendam dalam larutan ekstrak Lengkuas lalu diletakkan di atas media $N A$. Hasil dari penelitian ini sesuai dengan penelitian yang telah dilakukan Wahyu Susilowati (1997) yang menyatakan bahwa dengan menggunakan metode sumuran dapat menghasilkan diameter zona hambat yang besar. Dan diperkuat dalam penelitian Eko Prayoga (2013) Hal ini terjadi karena pada metode sumuran terjadi proses osmolaritas dari konsentrasi ekstrak yang 
lebih tinggi dari metode cakram. Pada metode sumuran setiap lubang di isi dengan konsentrasi ekstrak, maka osmolaritas terjadi lebih menyeluruh dan lebih homogen serta konsentrasi ekstrak yang dihasilkan lebih tinggi dan lebih kuat untuk menghambat pertumbuhan bakteri.

Terbentuknya daerah zona hambat menunjukkan terjadinya penghambatan pertumbuhan koloni bakteri yang diduga akibat pengaruh senyawa bioaktif yang terdapat pada ekstrak Lengkuas merah. Menurut penelitian Herni dan Shofia (2015) yang melakukan skrining fitokimia Lengkuas merah dan Lengkuas putih, menunjukkan hasil untuk ekstrak etanol rimpang Lengkuas merah positif mengandung golongan senyawa flavonoid, tannin, kuinon dan terpenoid. Selain itu ekstrak rimpang Lengkuas merah juga mengandung minyak atsiri seperti yang diungkapkan Kunia (2007), senyawasenyawa tersebut diduga merupakan senyawa yang berperan dalam menghambat pertumbuhan bakteri Klebsiella pneumoniae.

Pertumbuhan bakteri yang terhambat atau dapat disebabkan oleh penghambatan terhadap sintesis dinding sel, penghambatan terhadap fungsi membran sel, penghambatan terhadap sintesis protein atau penghambatan terhadap sintesis asam nukleat. Menurut Volk dan Wheeler (1988), minyak atsiri (seperti yang terkandung di dalam Lengkuas merah), dapat menghambat pertumbuhan atau mematikan bakteri dengan mengganggu proses terbentuknya membran atau dinding sel karena komponen struktural membran sel bakteri tersusun atas protein dan lipid, hal ini menyebabkan membran sel rentan terhadap zat kimia yang dapat menurunkan tegangan permukaan. Kerusakan membran sel menyebabkan terganggunya transport nutrisi (senyawa dan ion) melalui membran sel yang pada akhirnya dapat menyebabkan gangguan terhadap pertumbuhan bakteri. Volk dan Wheeler (1993) menambahkan bahwa walaupun dinding sel seperti yang terdapat pada bakteri memiliki struktur yang dapat memberikan kekuatan tambahan bagi sel, namun senyawa kimia seperti tannin yang juga terkandung dalam Lengkuas merah mempunyai sifat sebagai pengelat yang berefek spasmolitik, menciutkan atau mengkerutkan sel sehingga pertumbuhan bakteri terganggu.

Masduki (1996) juga menyatakan bahwa tannin memiliki daya antibakteri dengan cara mempresipitasi protein, karena diduga tannin mempunyai efek yang sama dengan senyawa fenolik. Tannin dapat bereaksi dengan membran sel, inaktivasi fungsi materi genetik. Sedangkan senyawa flavonoid seperti yang juga terkandung di dalam rimpang Lengkuas merah menurut Ajizah (2004), diduga menjadi penyebab gangguan terhadap pertumbuhan Klebsiella pneumoniae karena adanya efek fenolik dari flavonoid. Senyawa fenol dapat bersifat koagulator protein. Protein yang menggumpal tidak dapat berfungsi lagi, sehingga akan mengganggu pembentukan dinding sel bakteri sehingga pada akhirnya bakteri kehilangan kemampuan membentuk kolono dan menyebabkan kematian sel.

\section{KESIMPULAN}

Berdasarkan hasil penelitian yang dilakukan dapat disimpulkan bahwa ekstrak 
rimpang Lengkuas merah memiliki daya hambat terhadap bakteri Klebsiella pneumoniae yang resisten antibiotik seftriakson. Untuk metode cakram konsentrasi 100\%, 75\%, 50\%, 25\% dan $12,5 \%$ termasuk kategori sedang. Untuk metode sumuran konsentrasi $100 \%$ termasuk kategori sangat kuat, konsentrasi 75\%, 50\% dan $25 \%$ termasuk kategori kuat dan untuk konsentrasi $12,5 \%$ termasuk kategori sedang.

\section{SARAN}

Perlu dilakukan penelitian lebih lanjut tentang potensi antibakteri dari zat aktif yang terdapat dalam ekstrak rimpang Lengkuas merah.

\section{DAFTAR PUSTAKA}

Ajizah A, 2004. Sensitivitas Salmonella typhimurium Terhadap Ekstrak Daun Psidum guajava L. Jurnal Bioscientiae. 1: $31-38$

Borges, M. T., and Bresson, W. 2004. Delivery Methods for Introducing Endophitic Bacteria into Maize. Biocontrol. 49: 315-322.

Brisse. S., Fevre. C., Passer. V., Jeanjean. S. I., Tournebize, R., \& Diancourt. L., et al., 2009. Virulent Clones Of Klebsiella pneumonia Identification and Evolutionary Scenario Based on Genomik and Phenotypic Charaterization, Plos One, 4.

Davis, W. W., T.R. Stout. 1971. Disc plate method of microbiological assay. Journal of microbiology 22: 659-665.

Dwijendra, I. M. 2014. Aktivitas Antibakteri dan Karakterisasi Senyawa Fraksi Spos Lamellodysidea herbacea yang
Diperoleh dari Teluk Manado [skripsi]. Program Studi Farmasi FMIPA Universitas Sam Ratulangi, Manado.

Eka Prayoga. 2013. Perbandingan Efek Ekstrak Daun Sirih Hijau (Piper betle L.) Dengan Metode Difusi Disk dan Sumuran Terhadap Pertumbuhan Bakteri Staphylococcus aureus. SKRIPSI. Program Studi Pendidikan Dokter Fakultas Kedokteran dan Ilmu Kesehatan Universitas Islam Negeri Syarif Hidayatullah, Jakarta.

Harum, 2018. Isolasi dan Identifikasi Biomolekuler Bakteri Penyebab Penyakit Pneumonia yang Resisten Terhadap Antibiotik Seftriakson di RSUP Dr R. D Kandou. Skripsi. Fakultas Matematika dan Ilmu Pengetahuan Alam : Universitas Sam Ratulangi, Manado.

Kunia, K. 2007. Lengkuas Pengganti Formula.http://anekaplanta.wordpress.co m/author/plantus/ (31 Oktober 2018)

Masduki, I. 1996. Efek Antibakteri Ekstrak Biji Pinang (Areca catechu) terhadap $S$. aureus dan E. coli invitro. Jurnal Cermin Dunia Kedokteran. 109: 21-24

Misnadiraly, 2008. Penyakit Infeksi Saluran Napas Pneumonia Pada Anak, Orang Dewasa dan Usia Lanjut. Pustaka Obor Populer. Jakarta.

Mukti Abdul, H., Alsaggaf Hood, 2010. Dasar - dasar Ilmu Penyakit Paru, Surabaya : Erlangga.

Radji, M., 2011. Mikrobiologi Panduan Mahasiswa Farmasi dan Kedokteran. Penerbit Buku Kedokteran EGC, Jakarta. Sarro, A.D., G.D. Sarro. 2001. Adverse Reactions to Fluoroquinolones. An Overview on Mechanism Aspect. 
Current Medicinal Chemistry. 8 :371384.

Susilowati, W., Agustini, I., dan Indriastuti.1997. Uji Antibakteri Ekstrak Biji Alpokat (Persea Americana mill) dari Fraksi petroleum Eter. III (2) : 4853.

Utami ER.2012. Antibiotika, Resistensi, dan Rasionalitas terapi. Saintis $2012: 1(1)$ : $124-38$.

Volk, W. And Wheeler. 1988. The Basic Microbiology. Vol. I. Erlangga. Jakarta

Volk, W. A and Wheeler. 1993. Mikrobiologi Dasar Edisi Kelima. Jakarta : Erlangga.

Wahyu E. 2009. Aktivitas Antibakteri Ekstrak Etanol Daun Pepaya (Carica papaya L.) Terhadap Eschericia coli dan Staphylococcus aureus Multiresisten Antibiotik. Skripsi. Fakultas Farmasi : Universitas Muhammadiyah Surakarta. Wattimena, J. R, M. B Widianto, E. Y Sukandar., 1990. "Patofisiology", Pusat Antar Universitas Ilmu Hayati, Institut Tekhnologi Bandung, Bandung.

Wijayakusuma, H. M. 2000. Potensi Tumbuhan Obat Asli Indonesia sebagai Produk Kesehatan. Yogyakarta.

Yuharmen, dkk. 2002. Uji Aktivitas Antimikroba Minyak Atsiri dan Ekstrak Methanol Lengkuas (Lenguas galang) Jurusan Kimia, FMIPA. Universitas Riau,Riau 